\title{
Usability Testing on Android-based KMS for Pregnant Women using the USE Questionnaire
}

\author{
Halimah Tus Sadiah ${ }^{1 *}$, Mauladani Adi Gasbara ${ }^{1}$, Nyayu Siti Aminah Lily², \\ Eneng Tita Tosida ${ }^{3}$, Muhamad Saad Nurul Ishlah ${ }^{1}$ \\ I*Information System Department, Universitas Pakuan, Bogor, 16143 Indonesia \\ ${ }^{2}$ Pharmacy Department, Universitas Pakuan, Bogor, 16143 Indonesia \\ ${ }^{3}$ Computer Science Department, Universitas Pakuan, Bogor, 16143 Indonesia \\ *Corresponding author e-mail address: sadiahht@unpak.ac.id
}

\begin{abstract}
An Android-based medicines knowledge management system (KMS) application has been built as a result of a research about the usage of medicines on pregnant women. Usability testing is needed to be used to measure the success rate of the implementation of this mobile application. In this study, the Usefulness, Satisfaction and Ease of Use (USE) Questionnaire method is used, with quantitative and qualitative analysis. Based on the test results, it shows that the KMS application for pregnant women has a high usability result, with each component score, namely Usefulness reaches $86 \%$, Ease of Use of 86\%, and Satisfaction of 84\%. On average, 85\% indicates that the Android-based medicines KMS application for pregnant women has high quality attributes in ease of use. In addition, this application already has criteria to meet the needs of users, especially pregnant women, to easily find information and knowledge about medicines that are safe to consume during pregnancy to relieve pain or pregnancy complaints.
\end{abstract}

Keywords: Usability, Usability testing, KMS, USE Questionnaire 


\section{Introduction}

During pregnancy, pregnant women often experience complaints, such as: dizziness, nausea, vomiting, back pain and other complaints (Blenkinsopp et al., 2018). Due to the high cost of consulting a gynaecologist has caused pregnant women to consume medicines without a doctor's prescription. The use of drugs that are not in accordance with the rules of use can put the fetus at risk and can even cause fetal defects (MOH 2006 and New Guinea 2009).

Based on research conducted by Ratri et al (2015), it is known that pregnant women still have a lack of knowledge about medicines used during pregnancy. In addition, knowledge about the safety of medicines for pregnant women is still scattered and has not been collected in one container. Therefore, the KMS (Knowledge Management System) for Pregnant Women Medicines was developed using Android platform. KMS for Pregnant Women Medicine is a system that functions to create, store, manage and disseminate knowledge about pregnant women drugs based on the US FDA (United Status Food and Drug Administration) (Gramedia, 2018) (Sadiah, 2015) (Laudon and Laudon, 2018). The KMS medicine for pregnant women that has been built needs usability testing.

According to Nielsen (2012), usability is a quality attribute that determines how easy it is for a user to use the interface of an application or system (Nielsen, 2012) (Nurhadryani et al., 2013). Usability is one of the indicators used to measure the success rate of implementing information system products (Nielsen, 2012) (Hendra, 2018). As for usability testing, which is a test to measure the ease of use of an application and to evaluate whether an application is in accordance with user needs or not (Bastien, 2008) (Nurhadryani et al., 2013) (Barnum, 2015). Usability testing can also be interpreted as testing to measure and determine how well people can operate information system products (Lyles et al., 2014) (Constantinescu et al., 2018).

According to Holzinger (2005) usability testing can be done by means of the field observation method, questionnaire, and thinking aloud (Holzinger, 2005; Kaikkonen, 2005; Masood and Thigambaram, 2015; Alhadreti et al., 2017; Mayhew et al., 2018). The method used to measure the usability of KMS for pregnant women drugs was a questionnaire. One of the advantages of measuring using a questionnaire is the ease of recording and data extraction (Faria et al., 2016). One of the validated questionnaires is the questionnaire Usefulness, Satisfaction and Ease of Use (USE) or abbreviated as USE Questionnaire (Faria at al., 2016).

The USE Questionnaire is one of the questionnaire packages used as a measuring tool in conducting usability testing (Rizal et al., 2020; Suskamiyadi et al., 2014). The USE Questionnaire was designed by Arnie Lund with the aim of analyzing and summarizing the graphical usability interface where the model uses 3 factors, namely usefulness, satisfaction and ease of use (Lund, 2001). This study aims to measure the usability of KMS for Android-based pregnant women medicines using the USE Questionnaire. Research on usability testing was conducted by Faria et al (2016) regarding Evaluating the Usability Using USE Questionnaire: Mindboard System Use Case. In addition, in 2020 Rizal et al. have also conducted a study on usability testing entitled Usability testing mozita application based on use questionnaire model. 


\section{Materials and Methods}

\subsection{Time and Place of Research}

The KMS testing for pregnant women medicines was conducted in September 2020 in the Ciomas area, Bogor Regency.

\subsection{Tools and Materials}

The application tested in this study was an Android-based KMS for pregnant women medicines. This application has several functions, namely: F1 (Login), F2 (Function to display the Home page), F3 (Drug List), F4 (Detailed Drug Knowledge for pregnant women), F5 (Search Function by Drug Name), F6 (Search Function based on Disease Indication), F7 (Function displays the profile page), F8 (Function to display the drug safety specification page), F9 (Registration Function), F10 (Function to display the drug symbol knowledge page). Figure 1 shows pregnant woman medicines KMS interface for F1-F8 function. The KMS application for pregnant women medicines can run on the Android Operating System version from Android 5.0, Lollipop (API level 21) and above. The measuring instrument used is the USE Questionnaire.

\subsection{Method}

This study uses a questionnaire method based on USE Questionnaire. The USE Questionnaire in this study was adjusted according to the needs of pregnant women. There are 15 USE Questionnaire questions, where there are 5 questions for each usability component. Table 1 is the USE questionnaire package for Android-based KMS testing for pregnant women medicines. The USE Questionnaire that has been designed is then filled in by the respondent using a Likert scale of 1-5.

After the usability testing data is generated, the data is processed and analyzed using quantitative and qualitative analysis. Quantitative analysis is used to measure the level of ease of use of the KMS application for pregnant women drugs which is presented in the form of a percentage. Qualitative analysis is used to describe the obstacles found by pregnant women and as a means for users to provide suggestions for improving the KMS application for pregnant women drugs in order to meet user needs. The formula for calculating the percentage can be seen in equation (1). 


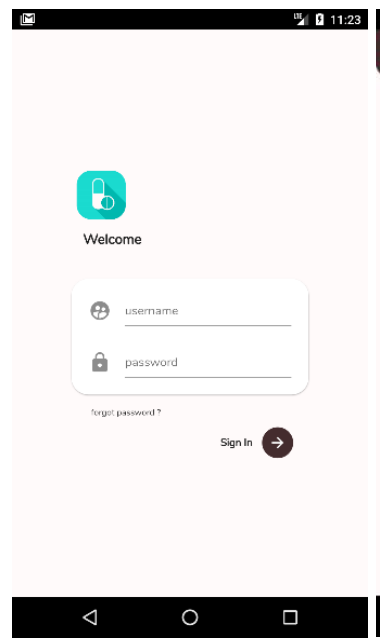

F1 (Login)

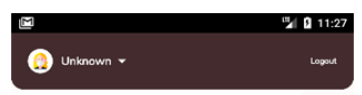

Cari Obat disini

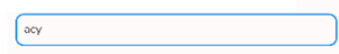

(1) $\mid \begin{gathered}\text { Acycovirus } \\ \text { coshrinos }\end{gathered}$ $\triangleleft$ $\mathrm{O}$ $\square$

F5 (Search function based on name)

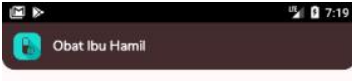

Selamat Malam Silahkan Pitih Kategori Obat

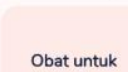

Ibu hamil

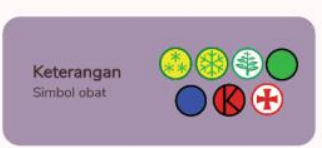

simbol obat $\bigcirc \otimes \oplus$

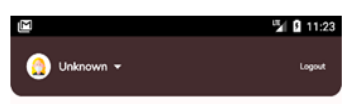

Cari Obat disini

search.
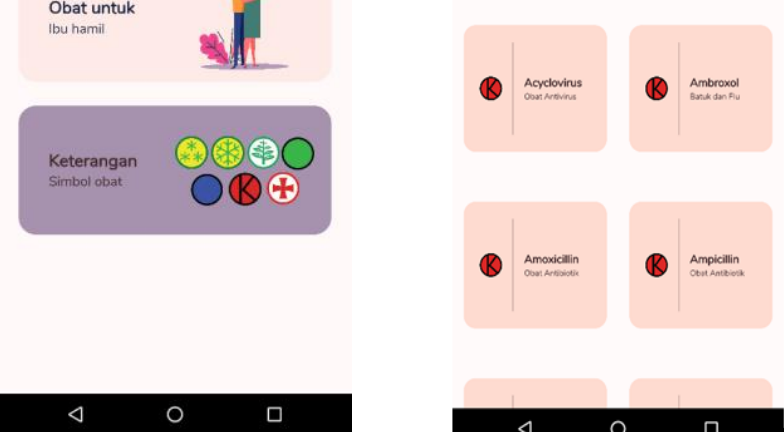

F2 (Function to display homepage)

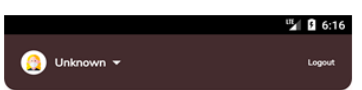

Cari Obat berdasarkan indikasi penyakit

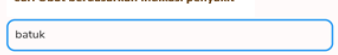

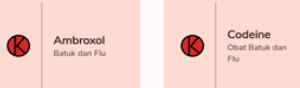

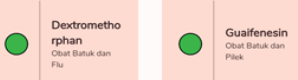

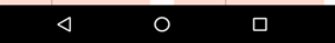

F6 (Search Function based on Disease Indication)
F3 (List of drugs)

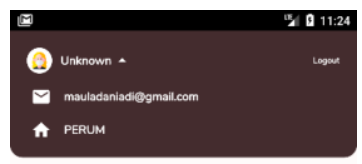

Pilih Obat
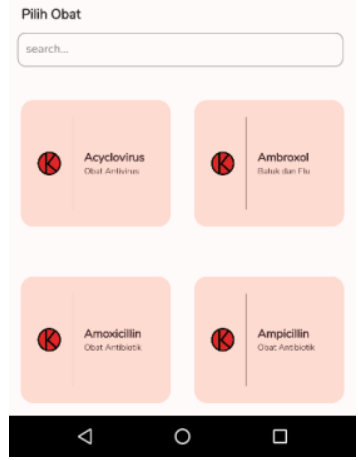

F7 (Profile page function)

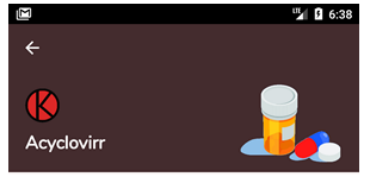

Pengetahuan Obat

न Deskripsi

$\{$ Dosis

[ె] Kategori Keamanan Obat Untuk Ibu

(1) Merk Dagang

v. Aturan Pemakaian Obat Dengen

a. Etek Samping

\section{F4 (Knowledge details)}

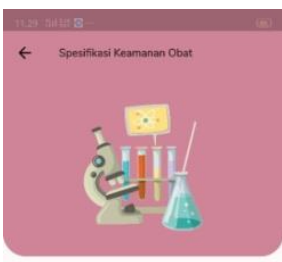

Karakter Fisik

kemsan
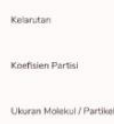

Kondis Pavien

Bentut seodan obat

F8 (Function displays the drug symbol knowledge page)

Figure 1: Pregnant women medicines KMS interface 
Table 1. The USE questionnaire package for testing Android-based KMS for pregnant women medicines

\begin{tabular}{|c|c|c|}
\hline Criteria & $\begin{array}{c}\text { Question } \\
\text { code }\end{array}$ & Question \\
\hline \multirow[t]{5}{*}{ Usefulness } & U1 & $\begin{array}{l}\text { KMS pregnant women medicine is useful for me in finding safe } \\
\text { drugs }\end{array}$ \\
\hline & $\mathrm{U} 2$ & $\begin{array}{l}\text { KMS for pregnant women helped me find safe drugs according to } \\
\text { complaints or indications of illness }\end{array}$ \\
\hline & $\mathrm{U} 3$ & $\begin{array}{l}\text { The drug information on the KMS application for pregnant women } \\
\text { drugs helped me identify drugs that pose a risk to the fetus }\end{array}$ \\
\hline & $\mathrm{U} 4$ & $\begin{array}{l}\text { KMS medicine for pregnant women is very useful for me because it } \\
\text { provides knowledge of safe medicine }\end{array}$ \\
\hline & U5 & Medicinal symbol information is useful to me \\
\hline \multirow[t]{5}{*}{$\begin{array}{l}\text { Ease of } \\
\text { Use }\end{array}$} & E1 & KMS medicine for pregnant women is very easy to use \\
\hline & E2 & KMS medicine for pregnant women is very simple \\
\hline & E3 & KMS drug for pregnant women user friendly \\
\hline & E4 & KMS medicine for pregnant women is very easy to operate \\
\hline & E5 & $\begin{array}{l}\text { I can use the KMS app for pregnant women without written } \\
\text { instructions }\end{array}$ \\
\hline \multirow[t]{5}{*}{ Satisfaction } & S1 & I am very happy in using this application \\
\hline & S2 & I am satisfied in finding safe drug information for pregnant women \\
\hline & S3 & I feel like I have to have this application on my cell phone \\
\hline & S4 & I am very interested in the knowledge contained in this application \\
\hline & S5 & $\begin{array}{l}\text { I recommended KMS android based pregnant women medicine to my } \\
\text { friends }\end{array}$ \\
\hline
\end{tabular}

$$
\text { Precentage }=\frac{\text { Amount filled }}{\text { Total } n u m b e r} \times 100 \%
$$

\section{Results and Discussion}

The usability testing consisting of 15 questions in the Table 1, was given to 15 respondents of pregnant women in the Ciomas area, Bogor Regency where the respondent data were obtained from patient data at the Klinik Bidan Dame. The characteristics of the respondents are shown in Table 2. The results of usability testing are grouped by age group (Table 3 ). 
Table 2.Characteristics of Respondents by age

\begin{tabular}{lc}
\hline \multicolumn{2}{c}{ Age (Year) } \\
\hline Less than 21 & $13 \%$ \\
$21-30$ & $60 \%$ \\
$31-40$ & $27 \%$ \\
\hline
\end{tabular}

Table 3. Usability Testing results by age group

\begin{tabular}{|c|c|c|c|c|c|c|c|c|c|c|c|c|c|c|c|c|c|}
\hline \multirow{3}{*}{$\begin{array}{c}\text { USE } \\
\text { Criteria }\end{array}$} & \multirow{3}{*}{$\begin{array}{r}\text { USE } \\
\text { Code }\end{array}$} & \multicolumn{15}{|c|}{ Respondents Answer } & \multirow{3}{*}{ Percentage } \\
\hline & & \multicolumn{3}{|c|}{$\begin{array}{l}\text { Age } \\
(<21)\end{array}$} & \multicolumn{7}{|c|}{ Age (21-30) } & \multicolumn{5}{|c|}{ Age (31-40) } & \\
\hline & & 苞 & 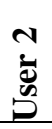 & 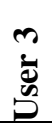 & 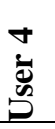 & $\begin{array}{l}n \\
\grave{D} \\
\mathscr{0} \\
\end{array}$ & $\begin{array}{l}b \\
\vdots \\
0 \\
0 \\
0\end{array}$ & م. & 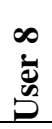 & $\begin{array}{l}a \\
\dot{0} \\
\stackrel{0}{0}\end{array}$ & 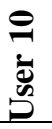 & 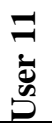 & 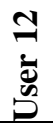 & 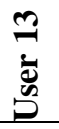 & 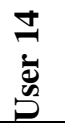 & 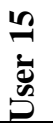 & \\
\hline \multirow{5}{*}{ Usefulness } & $\mathrm{U} 1$ & 5 & 5 & 5 & 4 & 5 & 4 & 5 & 4 & 4 & 4 & 4 & 4 & 4 & 4 & 5 & \multirow{5}{*}{$86 \%$} \\
\hline & $\mathrm{U} 2$ & 5 & 5 & 4 & 4 & 4 & 4 & 4 & 5 & 5 & 4 & 4 & 4 & 4 & 5 & 4 & \\
\hline & $\mathrm{U} 3$ & 5 & 4 & 5 & 4 & 5 & 4 & 4 & 4 & 4 & 4 & 4 & 4 & 4 & 5 & 5 & \\
\hline & U4 & 5 & 4 & 5 & 5 & 5 & 4 & 4 & 4 & 4 & 4 & 4 & 4 & 4 & 5 & 5 & \\
\hline & U5 & 4 & 4 & 5 & 4 & 4 & 4 & 4 & 4 & 4 & 5 & 4 & 4 & 4 & 4 & 4 & \\
\hline \multirow{5}{*}{ Ease of Use } & E1 & 5 & 4 & 4 & 4 & 5 & 4 & 5 & 4 & 4 & 4 & 4 & 4 & 4 & 5 & 5 & \multirow{5}{*}{$85 \%$} \\
\hline & E2 & 5 & 5 & 5 & 4 & 4 & 4 & 4 & 4 & 4 & 5 & 4 & 5 & 5 & 4 & 4 & \\
\hline & E3 & 4 & 4 & 4 & 5 & 5 & 4 & 5 & 4 & 5 & 4 & 4 & 4 & 4 & 4 & 4 & \\
\hline & E4 & 4 & 4 & 4 & 5 & 5 & 4 & 5 & 4 & 4 & 4 & 4 & 4 & 3 & 4 & 4 & \\
\hline & E5 & 4 & 5 & 4 & 4 & 4 & 3 & 5 & 3 & 5 & 4 & 4 & 5 & 3 & 4 & 4 & \\
\hline \multirow{5}{*}{ Satisfaction } & S1 & 5 & 5 & 5 & 4 & 5 & 4 & 4 & 4 & 4 & 5 & 4 & 5 & 4 & 4 & 5 & \multirow{5}{*}{$84 \%$} \\
\hline & S2 & 4 & & 5 & 4 & 5 & 4 & 5 & 4 & 4 & 5 & 4 & 5 & 4 & 4 & 5 & \\
\hline & S3 & 4 & 4 & 4 & 4 & 5 & 3 & 4 & 3 & 4 & 4 & 3 & 4 & 3 & 5 & 4 & \\
\hline & S4 & 4 & 5 & 5 & 4 & 5 & 4 & 5 & 4 & 5 & 4 & 4 & 4 & 5 & 4 & 5 & \\
\hline & S5 & 4 & 4 & 4 & 4 & 4 & 4 & 5 & 3 & 4 & 4 & 4 & 4 & 4 & 4 & 4 & \\
\hline
\end{tabular}

By using equation 1, the value of each of the usability testing criteria for the USE Questionnaire is generated, namely $86 \%$ usefulness, $86 \%$ Ease of Use, and $84 \%$ satisfaction. The percentage value of the Usefulness component obtained from usability testing, which is a value of $86 \%$, this value is the average value of 3 age groups for 5 questionnaire questions as given in Table 1. Based on these results it can be concluded that the Android-based KMS application for Pregnant Women Medicines 
has a positive influence on pregnant women. Users or pregnant women believe that the Androidbased KMS application for Pregnant Women Medicines is very useful because it helps find knowledge of drug safety for pregnant women so that pregnant women have knowledge about the use of drugs they will consume. The Android-based KMS application for pregnant women drugs has functioned in accordance with user needs. However, to improve the usability of the application, there are suggestions from users, namely the addition of a bookmark feature so that users can save the medicines they have been looking for.

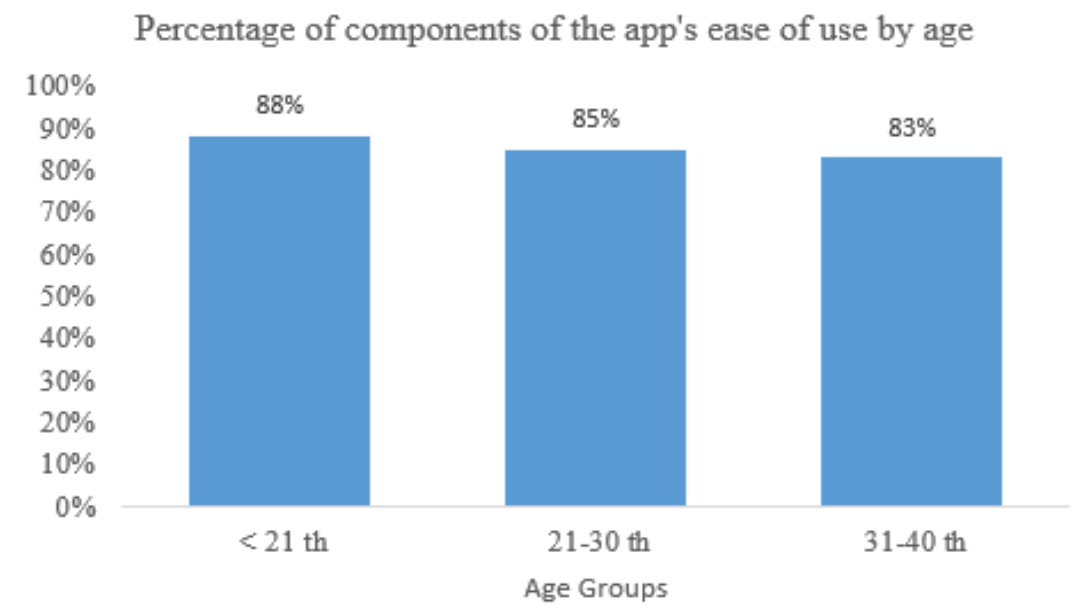

Figure 2: Percentage of components of the app's ease of use by age

The results of usability testing based on the operation of the KMS application for pregnant women by age group (Figure 2), showed that for 31-40 years the percentage value was $83 \%$. Below $85 \%$. This means that the age factor greatly affects usability testing. However, the average percentage of the ease of use component from the results of usability testing obtained a value of 85\% (Table 1). Based on this value, it can be concluded that the Android-based KMS application for pregnant women drugs as a whole has ease in usage.

Based on usability testing, the Satisfaction component value was $84 \%$. This score indicates a high enough satisfaction. However, the value obtained is still less than $85 \%$. This is because 4 users or 4 pregnant women do not yet have smart phones that have Android Operating System specifications version Android 5.0, Lollipop so they are not satisfied because they cannot download and install directly on their smart phones.

$$
\begin{aligned}
& \text { Precentage }=\frac{\text { Amount filled }}{\text { Total number }} \times 100 \% \\
& \text { Precentage }=\frac{956}{1125} \times 100 \%=85 \%
\end{aligned}
$$

Based on the results of calculation (2) analysis using equation 1, it is known that the results of 
usability testing using the USE Questionnaire show a high value, 85\%. A high usability value of $85 \%$ indicates that the Android-based KMS application for pregnant women drugs has high quality attributes in ease of use. In addition, this application already has criteria to meet the needs of users, especially pregnant women, in order to easily find information and knowledge about drugs that are safe to consume during pregnancy to relieve pain or pregnancy complaints.

\section{Conclusion}

To sum up, the Android-based KMS application for Pregnant Women Medicines that has been built has been tested using the USE Questionnaire usability approach. The results show that the KMS application for pregnant women medicines has a high usability value, with each component, Usefulness reaches $86 \%$, Ease of Use of $86 \%$, and Satisfaction of $84 \%$. As a whole, the results of usability testing using the USE Questionnaire showed a high value, which is $85 \%$. A high usability value of $85 \%$ indicates that the Android-based KMS application for pregnant women drugs has high quality attributes in ease of use. In addition, this application already has criteria to meet the needs of users, especially pregnant women, to easily find information and knowledge about drugs that are safe to consume during pregnancy to relieve pain or pregnancy complaints.

\section{Acknowledgments}

The authors would like to thank the Ministry of Research, Technology and Higher Education or Ministry of Research and Technology, National Agency for Research and Innovation and LLDIKTI who have funded this research. Thanks to LPPM Pakuan University who has helped in the implementation of the research.

\section{References}

Alhadreti, Obead, Elbabour, Fatma, Mayhew, and Pam. (2017) Eye Tracking in Retrospective Think-Aloud Usability Testing:Is there Added Value?, Journal of Usability Studies, 12 (3), 95-110.

Barnum, C. (2015) The State of UX Research, JUS (Journal of Usability Studies), 15(1), 1-7.

Bastien, J. M. C. (2008) Usability testing: a review of some methodological and technical aspects of the method, International journal of medical informatics, 79(4), 18-23.

Blenkinsopp, A., Duerden, M., and Blenkinsopp, J. (2018) Symptoms in the Pharmacy, A Guide to the Management of Common Illnesses (8 ed.), New York: Willey Backwell.

Constantinescu, G., Kuffel, K., King, B., Hodgetts, W., and Rieger, J. (2018) Usability testing of an mHealth device for swallowing therapy in head and neck cancer survivors Show less, Health Informatics Journal, 25(4), 1373-1382.

Depkes RI. (2006) Pedoman Pelayanan Farmasi untuk Ibu Hamil dan Menyusui. Jakarta: Direktorat Bina Farmasi Komunitas dan Klinik Departemen Kesehatan RI. 
Faria, T. V. M., Pavanelli, M., and Bernardes, J. L. (2016) Evaluating the Usability Using USE Questionnaire: Mindboard System Use Case, Springer International Publishing Switzerland.

Zaphiris, P. and Ioannou, A. (2016) (Eds.): LCT 2016, LNCS 9753, 518-527.

Gramedia, B. K. (2018) MIMS (18 ed.). Jakarta: MIMS Pte Ltd.

Hendra, and Arifin, Y. (2018) Web-based Usability Measurement for Student Grading Information System, Procedia Computer Science, 135 (1), 238-247.

Kaikonen, A., Kallo, T., Kekalainen, A., Kankainen, A., and Cankar, M. (2005) Usability Testing of Mobile Applications: A Comparison between Laboratory and Field Testing, JUS (Journal Of Usability Studies), 1(1), 4-16.

Laudon, K. C., and Laudon, J. P. (2018) Management Information System Managing The Digital Firm (15 ed.). New York: Pearson.

Lund, A. M. (2001) Measuring Usability with the USE Questionnaire, [internet],[downloaded 2020 August 3], Available at: http://www.stcsig.org/usability/newsletter/0110_measuring_with_use.html.

Lyles, C.R., Sarkar, U., and Osborn, C.Y. (2014) Getting a technology-based diabetes intervention ready for prime time: a review of usability testing studies. Curr Diab Rep 2014, 15, 1-12.

Mayhew, Pamela, Alhadreti, and Obead (2018) Are two pairs of eyes better than one? A comparison of concurrent think-aloud and co-participation methods in usability testing, Journal of Usability Studies, 13 (4), 177-195.

Masood, M., and Thigambaram, M., (2015) The Usability of Mobile Applications for Pre-schoolers, Procedia - Social and Behavioral Sciences, 197( 1) , 1818 - 1826.

Nielsen, J. (2012) Handbook on Usability 101: Introduction to Usability 4th Ed (New Jersey) Prentice Hall.

Nielsen, J. (2012) Usability 101: Introduction to Usability, [Internet],[diakses tanggal 5 Sepetember 2020], Tersedia pada https://www.nngroup.com/articles/usability-101-introduction-to-usability/

Nugrahini, D. (2009) Evaluasi Penggunaan Obat Pada Pasien Ibu Hamil Di Poliklinik Obstetri Dan Ginekologi Rsud Dr. Moewardi. Skripsi. Surakarta: Universitas Muhammadiyah Surakarta.

Nurhadryani, Y., Sianturi, S. K., Hermadi, I., and Khotimah, H. (2013) Usability Testing to Enhance Mobile Application User Interface, Jurnal Ilmu Komputer Agri Informatika, 2(2), 83-93.

Ratri, G., Indah, A., Amirah, W., Faris, A. E., Wahyuni, S., Khadijah, T., and Ainun, R. (2015) Pengetahuan Ibu Tentang Pengobatan Selama Masa Kehamilan, Jurnal Farmasi Komunitas, 2(2), 47-51.

Rizal, M. F., Widodo, A. P., Adi, K., Riyanto, D. E. R., and Nurhayati, O. D. (2020) Usability testing mozita application based on use questionnaire model, Journal of Physics, Conference Series 1524012104 .

Sadiah, H. T. (2015) ICT Literacy Analysis of Soybean Farmers and Development of soybean KMS using 
Information Architecture Concept, Thesis, Bogor: IPB.

Suskamiyadi, Nurhadryani, Y., Sukoco, H. (2014) Development and Usability Test of Management Information System Student Attendance and Grades Test Monitoring, Jurnal Ilmu Komputer Agri Informatika, 3(1), 58-66. 